ENGENHARIAS, TECNOLOGIA, GESTÃO E TURISMO

ENGINEERING, TECHNOLOGY, MANAGEMENT AND TOURISM INGENIERÍA, TECNOLOGÍA, ADMINISTRACIÓN Y TURISMO

PESQUISA SOBRE AS PROPRIEDADES DE RESISTÊNCIA DO GEOPOLÍMERO FEITO DE RESÍDUOS DE MINAS DE TUNGSTÉNIO E VIDRO RECICLADO

\title{
RESEARCH ON STRENGTH PROPERTIES OF GEOPOLYMER BASED ON TUNGSTEN MINE WASTE AND RECYCLED GROUND GLASS
}

INVESTIGACIÓN SOBRE LAS PROPIEDADES DE RESISTENCIA DEL GEOPOLÍMERO HECHO DE RESIDUOS DE MINERÍA DE TUNGSTENO Y VIDRIO RECICLADO

Szymon Dawczyński ${ }^{1}$

Paulina Cieśla ${ }^{1}$

Marcin Górski ${ }^{1}$

Rafał Krzywon' ${ }^{1}$

${ }^{1}$ Silesian University of Technology, Gliwice, Polónia

Szymon Dawczyński - szymon.dawczynski@polsl.pl | Paulina Cieśla - paulinaciesla6@gmail.com | Marcin Górski - marcin.gorski@polsl.pl | Rafał Krzywoń - rafal.krzywon@polsl.pl

Corresponding Author

Szymon Dawczyński

Silesian University of Technology

Akademicka 2A, 44-100 Gliwice, Polónia

szymon.dawczynski@polsl.pl
RECEIVED: $12^{\text {th }}$ April, 2018

ACCEPTED: $18^{\text {th }}$ September, 2018 


\title{
RESUMO
}

Introdução: Os geopolímeros são os materiais inorgânicos modernos obtidos como resultado da reação química sob condições fortemente alcalinas. As principais vantagens destes materiais são: parâmetros de alta resistência; resistência ao fogo; resistência ao gelo e resistência a ambientes agressivos. Por causa da menor emissão de $\mathrm{CO}_{2}$ durante o processo de produção, eles também são considerados materiais ecológicos em comparação com materiais de cimento Portland comuns.

Objetivos: O objetivo da investigação foi definir o impacto da adição de vidro moído reciclado nas propriedades mecânicas do aglomerante geopolimérico produzido a partir de resíduos de minério de tungsténio.

Métodos: Os parâmetros de resistência de amostras geopoliméricas foram determinados com base no teste de flexão e teste de compressão.

Resultados: As amostras geopoliméricas que contêm 20\%, 40\% e $80 \%$ de vidro moído reciclado apresentam resistência à flexão similar. A resistência à compressão de geopolímeros à base de vidro aumenta com o crescente conteúdo de vidro moído reciclado.

Conclusões: Em termos de resistência à flexão, a composição mais favorável foi a mistura composta por $60 \%$ de vidro moído reciclado e $40 \%$ de resíduos de minério de tungsténio. Em termos de resistência à compressão, a composição mais favorável foi a mistura composta de $80 \%$ de vidro moído reciclado e $20 \%$ de resíduos de minério de tungsténio.

Palavras-chave: geopolímero; ligante geopolimérico; resíduos de minério de tungsténio; vidro moído reciclado.

\begin{abstract}
Introduction: Geopolymers are the modern inorganic materials obtained as a result of chemical reaction under strongly alkaline conditions. The main advantages of these materials are: high strength parameters, fire resistance, frost resistance and resistance to aggressive environment. Because of lower $\mathrm{CO}_{2}$ emission during production process, they are also considered as environmentally friendly materials in comparison to ordinary Portland cement (OPC) systems.

Objectives: The aim of the investigation was to define the impact of recycled ground glass addition on mechanical properties of geopolymeric binder made from tungsten mine waste.

Methods: The strength parameters of geopolymeric samples were determined on the basis of three-point flexural test and uniaxial compression test.

Results: The geopolymer samples that contain $20 \%, 40 \%$ and $80 \%$ of recycled ground glass present similar flexural strength. The compressive strength of glass-based geopolymers increases with growing content of recycled ground glass.

Conclusions: In terms of flexural strength, the most favourable composition was the mixture composed of $60 \%$ recycled ground glass and $40 \%$ tungsten mine waste. In terms of compressive strength, the most favourable composition was the mixture composed of $80 \%$ recycled ground glass and $20 \%$ tungsten mine waste.
\end{abstract}

Keywords: geopolymer; geopolymeric binder; tungsten mine waste; recycled ground glass.

\section{RESUMEN}

Introducción: Los geopolímeros son los materiales inorgánicos modernos obtenidos como resultado de la reacción química bajo condiciones fuertemente alcalinas. Las principales ventajas de estos materiales son: parámetros de alta resistencia, resistencia al fuego, resistencia a las heladas y resistencia al entorno agresivo. Debido a la menor emisión de $\mathrm{CO}_{2}$ durante el proceso de producción, también se consideran materiales ecológicos en comparación con los materiales ordinarios de cemento Portland.

Objetivos: El objetivo de la investigación fue definir el impacto de la adición de vidrio triturado reciclado en las propiedades mecánicas del aglutinante geopolimérico a partir de desechos de la mina de tungsteno.

Métodos: Los parámetros de fuerza de las muestras geopoliméricas se determinaron sobre la base de la prueba de flexión de tres puntos y la prueba de compresión.

Resultados: Las muestras de geopolímeros que contienen $20 \%, 40 \%$ y $80 \%$ de vidrio triturado reciclado presentan una resistencia a la flexión similar. La resistencia a la compresión de los geopolímeros basados en vidrio triturado aumenta con el creciente contenido de vidrio triturado reciclado.

Conclusiones: En términos de resistencia a la flexión, la composición más favorable fue la mezcla compuesta por $60 \%$ de vidrio triturado reciclado y $40 \%$ de desechos de la mina de tungsteno. En términos de resistencia a la compresión, la composición más favorable fue la mezcla compuesta de un $80 \%$ de vidrio reciclado y un $20 \%$ de desechos de la mina de tungsteno.

Palabras Clave: geopolímero; aglutinante geopolimérico; residuos de la mina de tungsteno; vidrio triturado reciclado. 


\section{INTRODUCTION}

From a chemical point of view, the term "geopolymer" refers to a wide group of modern inorganic binders obtained as a result of chemical reaction under strongly alkaline conditions. Geopolymer synthesis, also known as geopolymerization, involves combining powdered solid precursor rich in silicon (Si) and aluminium (Al) with an alkaline solution. The product of chemical reaction is 3-dimensional amorphous aluminosilicate network built up of cross linked $\mathrm{SiO}_{4}$ and $\mathrm{AlO}_{4}$ tetrahedral units (Davidovits, 2008). Connection between tetrahedral is provided by bridging oxygen atoms. The negative charge of $\mathrm{AlO}_{4}$ tetrahedron is balanced by positive metal ions such as sodium, potassium, barium, lithium or calcium.

Generally, alkali-activation technology provides numerous advantages over ordinary Portland cement (OPC) systems. Apart from being environmentally friendly, geopolymers are also characterized by extraordinary properties such as high flexural and compressive strength, excellent resistance to aggressive environment (acids, sulphates, chlorides) and ability to withstand extreme weather conditions and corrosion attack (Provis and van Deventer, 2009).

\section{THEORETICAL FRAMEWORK}

In practice, geopolymer synthesis starts with mixing finely ground aluminosilicate material with an alkaline solution. Currently, geopolymeric binders may be produced of a wide range of solid materials including industrial by-products (e.g. coal fly ashes, blast furnace slag) and primary raw materials (calcined clays). Alkaline activator is usually a combination of sodium and potassium hydroxide and silicate. Distilled water is often added to the mixture in order to provide smooth consistency, which in turn allows for easier mixing and moulding of the samples. The selection of raw materials becomes a very significant stage in formation of geopolymeric binders because it strongly influences resulting properties such as workability, setting behaviour, physical and chemical features of the final product. Moreover, various types of additives may be introduced into the mixture in order to enhance specific material properties. The most commonly added materials include: metakaolin; ground glass; fly ash; pozzolan; kaolinite and silica sand. Addition of heat resistance fillers such as chamotte, corundum, wollastonite, fly ash and carbon, basalt or ceramic fibres may help to control shrinkage (Vickers, van Riessen, Rickard, 2015). Moreover, the natural aggregates (e.g. limestone, granite or schist) used for the production of Ordinary Portland Cement (OPC) concrete are also suitable for the production of geopolymeric concrete. According to Provis and van Deventer (2009), the formation of geopolymers consists of two basic steps: mixing of ingredients and heat-curing. In most cases, geopolymeric binders are allowed to be cured at room temperature, however heat-curing is more favourable. It was also proved that temperature and the time of curing strongly influence compressive strength of geopolymers. Moreover, the fastest strength increase is observed during first 24 hours of heat treatment (Adam and Horianto, 2014).

In order to obtain satisfactory mechanical properties of geopolymers, source materials should contain an optimal amount of reactive silica and alumina. Recycled glass shows great potential for use in geopolymer technology because it contains a lot of reactive silica and is chemically and physically homogeneous (Christiansen, 2013). Moreover, such a high content of silica may eliminate the need for sodium silicate in the starting mixture. However, glass cullet contains relatively small amount of alumina, what may negatively affect the stability and mechanical properties of the final product. Geopolymer composition in this case should be carefully designed and a proper amount of materials rich in reactive alumina should be introduced into the mixture (Vafaei and Allahverdi, 2017).

\section{METHODS}

A comprehensive research program has been established to investigate the physical and mechanical properties of geopolymer made from tungsten mine waste. In this paper, only the influence of recycled ground glass addition on strength parameters is discussed.

\subsection{Materials used}

Tungsten mine waste was obtained from Panasqueira mine during international cooperation under the European Union's Horizon 2020 Research and Innovation Staff Exchange programme (REMINE, 2018). It is worth to mention that Panasqueira mine is one of the oldest tungsten mines in Europe and it is located in the Municipality of Covilhã, District of Castelo Branco. Currently, Panasqueira mine produces between 100-200 tonnes of waste material per day (Sangiorgi et al., 2016). During the tungsten excavation two main groups of waste are produced. First are coarse aggregates which are by-products of rock blasting. Such aggregates are used in small quantities for the construction of the road surfaces. Second by-product of tungsten mining is waste mud accumulated in large lagoons accounting for several million tonnes (Pacheco-Torgal et al., 2008). Over the years of mining activity, the heaps of waste mud have reached enormous proportions. In the area of former plant called Rio, about $730000 \mathrm{~m}^{3}$ of tungsten mine waste are stored, while the Barroca Grande plant accumulated over $1.1 \mathrm{million}^{3}$ of waste mud. The results of the diffractometer study (X-ray power diffraction system) indicated that the waste mud consists mainly of quartz and muscovite (Pacheco-Torgal et al., 2007). While analysing the chemical composition, tungsten mud contains a high 
percentage of silica and alumina. Small quantities of sulphur, titanium and magnesium oxide are also present in the sample. Moreover, tungsten waste mud consists of relatively large amount of iron and potassium oxide which according to PachecoTorgal et al. (2005) may have a significant impact on the compressive strength of geopolymer binder. Considering the composition of material used as a precursor, it can be concluded that waste mud shows potential for use in geopolymer technology due to its relatively high percentage of silica and alumina which may guarantee a successful result of alkali-activation processes.

In this research, collected in Panasqueira mine waste mud was first dried in the oven and then manually sieved to obtain fine powder, with the granulation not bigger than 500 micrometres $(0.5 \mathrm{~mm})$.

Soda-lime glass is the least expensive and the most widely used type of glass constituting over $90 \%$ of all glass produced. Such glass is primarily used for the production of bottles, everyday drinking glasses, jars and also for window glass, where chemical and high temperature resistance are not required. Recycled glass powder (cullet) is normally made from soda-lime glass of type used for glass containers. Standard composition of soda-lime glass contains mainly sodium oxide, calcium oxide and silica which is favourable in terms of geopolymerization process.

To obtain the ground glass for the research, first some clear bottles were collected and then with the use of Los Angeles machine a fine cullet was made. Similarly, as it was in the case of tungsten mud waste, also the ground glass was manually sieved to obtain grain fraction from 0 to $0.5 \mathrm{~mm}$.

A combination of both sodium hydroxide and sodium silicate solution was applied as an alkaline activator in geopolymer formation. Sodium-containing solutions were chosen because they are less expensive and more widely available than potassium-based ones. The solution of sodium hydroxide $(\mathrm{NaOH})$ was made from pellets (with $97.5 \%$ purity and molar mass of $40 \mathrm{~g} / \mathrm{mol}$ ) which were dissolved in demineralised water. The final $\mathrm{NaOH}$ solution of $10 \mathrm{M}$ concentration was prepared 24 hours before forming the samples to allow time for liquid equilibrating.

The second liquid ingredient used in the experiment included sodium silicate solution of R-145 type. While taking into consideration its chemical composition, the molar ratio $\left(\mathrm{SiO}_{2} / \mathrm{Na}_{2} \mathrm{O}\right)$ was equal to 2.6 and the solid content $\left.\left(\mathrm{Na}_{2} \mathrm{O}+\mathrm{SiO}\right)_{2}\right) \mathrm{ranged}$ between $39-43 \%$. According to specifications, the relative density of waterglass solution was equal to about $1.45-1.48 \mathrm{~g} / \mathrm{cm}^{3}$. The liquid ingredients such as sodium hydroxide and sodium silicate were combined together in ratio 4.0.

\subsection{Samples preparation}

The geopolymer samples were synthesized from various proportions of waste mud and recycled ground glass (Table 1).

Table 1 - Proportion of solid ingredients in individual samples

\begin{tabular}{cccc}
\hline no. & sample & ground glass $(w / w)$ & waste mud $(w / w)$ \\
\hline 1 & GG 20 & 20 & 80 \\
2 & GG 40 & 40 & 60 \\
3 & GG 60 & 60 & 40 \\
4 & GG 80 & 80 & 20 \\
\hline
\end{tabular}

Preparation of geopolymer samples is an important stage which strongly influences the final characteristics of the finished products, their microstructure and resulting mechanical properties. The formation of geopolymer samples consists of three main steps: mixture proportioning and mixing, casting and heat curing.

Weighing of raw materials was performed with use of the laboratory scale accurate to $1.0 \mathrm{mg}$. The dry ingredients such as tungsten waste mud and ground glass were dry mixed before being added to the alkaline solution. Solid components were blended using putty knife until the material became homogenous. Then, the sodium silicate and sodium hydroxide ( $\mathrm{NaOH}$ ) solutions were combined together and mixed for 5 minutes. The next step involved adding the liquid to the solid constituents and precise mixing until the geopolymer paste became smooth and homogenous. The time and the way of mixing are very significant factors that strongly affect the quality of the finished sample. The distilled water was also added to the mixture in order to provide more fluid consistency and enable easier mixing. The excessive amounts of water contained in the samples may lead to drying shrinkage and occurrence of cracks. This in turn may cause material weakening and reduction of strength. Such phenomenon was also considered and the water dosing was carefully controlled. Finally, the following dependence was observed - the higher the ground glass content, the lower the water demand of geopolymer sample. The second stage involved pouring the geopolymer mixture into the special mould made out of Plexiglas. The choice of Plexiglas instead of steel was made in order to avoid any interaction between mixture components and internal walls of the mould during casting and curing process. The mould provided a space for six specimens with dimensions $40 \times 40 \times 160 \mathrm{~mm}$. The mixture was carefully placed into the mould using a putty knife. After casting, the geopolymer samples were wrapped in protective 
film to prevent water evaporation and to protect them against the impact of humidity during the curing process. Generally, alkaliactivated binders are allowed to be cured at ambient temperature, however heat-curing is more favourable and results in higher compressive and flexural strength of the final product. For this reason, the geopolymer samples were cured in a climatic chamber for 24 hours at temperature $60^{\circ} \mathrm{C}$. After transferring from the mould, the geopolymer specimens were stored at room temperature (about $20^{\circ} \mathrm{C}$ ) for the next 27 days.

\subsection{Mechanical behaviour analysis}

Mechanical parameters of geopolymeric samples were determined on the basis of three-point flexural test and uniaxial compression test. The strength tests were carried out using PILOT automatic compression-flexural tester (Controls S.p.A., Italy) in accordance with the Polish Standard PN-EN 1015-11:2001: Methods of test for mortar for masonry - Part 11: Determination of flexural and compressive strength of hardened mortar. The following standard provides the detailed requirements connected with testing of masonry samples. The three-point bending test was performed using geopolymer prisms with dimensions $40 \times 40 \times 160$ mm. During bend-testing, the samples were subjected to the concentrated force $\mathrm{F}$ acting in the middle of the beam span (Figure 1, left). The distance between supporting pins was equal to $100 \mathrm{~mm}$. The loading pin was gradually lowered at a constant rate $(50 \mathrm{~N} / \mathrm{s})$ until failure occurred. The flexure test was carried out using four geopolymer prisms, each of them contained different amount of ground glass (Table 1). Bending strength was determined on the basis of the following relationship:

$$
\mathrm{f}_{\mathrm{b}}=1.5 \times\left(\frac{\mathrm{Fl}}{\mathrm{bd}^{2}}\right)
$$

where:

$\mathrm{F}$ - destructive force $[\mathrm{N}]$,

I- span length [mm],

$\mathrm{b}$ - width of the sample [mm],

$\mathrm{d}$ - height of the sample [mm].

Uniaxial compression test was carried out on the portions of prisms previously broken in flexure - two parts of each sample were examined. The geopolymer specimens were placed in between two steel plates (Figure 1, right) and axially loaded by two opposing forces directed towards each other. The moveable head of the testing machine was gradually lowered until the sample broke. The uniaxial compressive strength is calculated with the use of the following formula:

$$
R=\frac{P}{A}
$$

where:

$\mathrm{P}$ - critical compressive force $[\mathrm{N}]$,

A-cross-sectional area subjected to compression $\left[\mathrm{mm}^{2}\right]$.
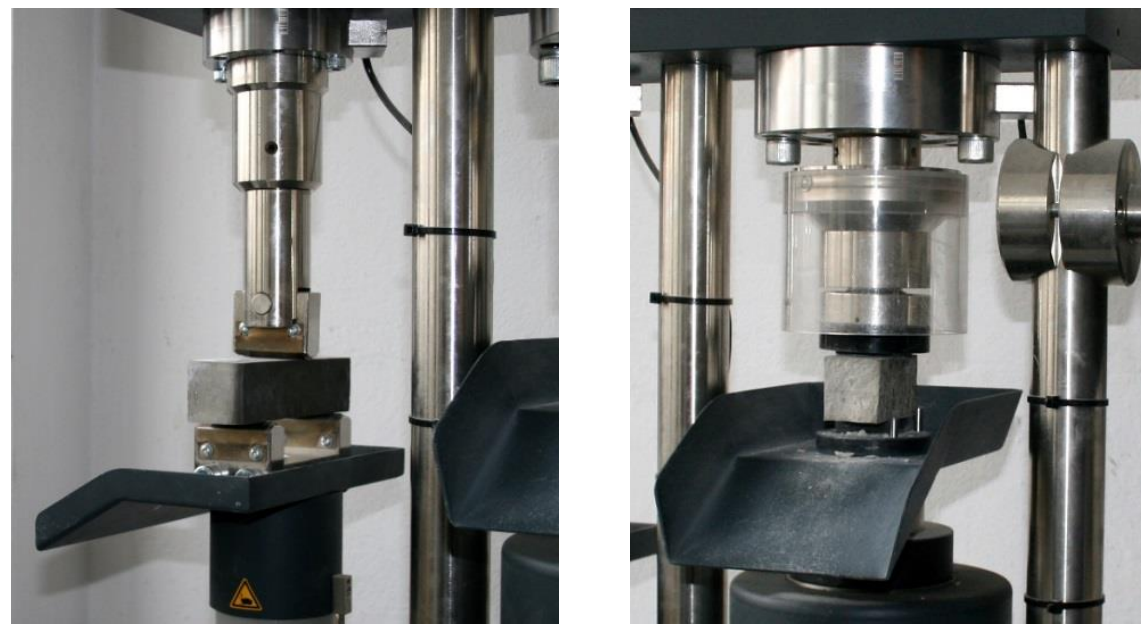

Figure 1 - Left: geopolymer beam subjected to bending. Right: half of the beam exposed to uniaxial compression. 


\section{RESULTS}

Flexural strength of geopolymer samples is shown in Table 2. The values of bending strength were determined on the basis of destructive force according to the equation (1). In most cases, as a result of the test an irregular crack formed in the middle of the sample (perpendicularly to the longitudinal axis of the beam), where the loading pin was applied. In case of specimen with the highest ground glass content (GG80), bending crack also formed in the middle of the beam, however its shape was completely different - except one main crack there were also some smeared cracks.

Table 2 - Results of three-point bending tests

\begin{tabular}{ccc}
\hline & Bending & \\
\hline Sample & Destructive force $F[\mathrm{kN}]$ & Strength $\mathrm{f}_{\mathrm{b}}[\mathrm{MPa}]$ \\
\hline GG20 & 0.778 & 1.902 \\
GG40 & 0.893 & 2.093 \\
GG60 & 1.309 & 3.093 \\
GG80 & 0.778 & 1.951 \\
\hline
\end{tabular}

The destructive force magnitudes in compression tests are presented in Table 3. On the basis of these values and according to equation (2) the compressive strength of geopolymer samples were calculated (Table 4).

Table 3 - Results of uniaxial compression test - values of destructive forces.

\begin{tabular}{cccc}
\hline & \multicolumn{3}{c}{ Compression } \\
\hline Sample & Force $P_{1}[\mathrm{kN}]$ & Force $P_{2}[\mathrm{kN}]$ & Mean value P $[\mathrm{kN}]$ \\
\hline GG20 & 9.16 & 8.49 & 8.83 \\
GG40 & 13.90 & 13.59 & 13.75 \\
GG60 & 21.96 & 19.23 & 20.60 \\
GG80 & 73.53 & 82.50 & 78.02 \\
\hline
\end{tabular}

Table 4 - Results of uniaxial compression test - compressive strength values.

\begin{tabular}{|c|c|c|c|}
\hline \multicolumn{4}{|c|}{ Compression } \\
\hline Sample & Strength $\mathbf{R}_{1}[\mathrm{MPa}]$ & Strength $\mathrm{R}_{\mathbf{2}}$ [MPa] & Mean value $R$ [MPa] \\
\hline GG20 & 5.73 & 5.31 & 5.52 \\
\hline GG40 & 8.69 & 8.49 & 8.59 \\
\hline GG60 & 13.73 & 12.02 & 12.88 \\
\hline GG80 & 45.96 & 51.56 & 48.76 \\
\hline
\end{tabular}

\section{DISCUSSION}

While considering the results of bending test, it can be noticed that flexural strength of geopolymer samples varies with growing amount of ground glass addition. Analysing the results in Table 2, bending strength initially increases with increasing amount of ground glass. The geopolymer sample that contains $60 \% \mathrm{w} / \mathrm{w}$ glass present the highest flexural strength which is equal to 3.1 $\mathrm{MPa}$. Addition of glass powder up to $80 \% \mathrm{w} / \mathrm{w}$ leads to the reduction of strength which then equals only $1.95 \mathrm{MPa}$. Moreover, geopolymer samples that contain $20 \%, 40 \%$ and $80 \% \mathrm{w} / \mathrm{w}$ ground glass show very similar flexural strength which is respectively 1.90; 2.09; $1.95 \mathrm{MPa}$. The obtained results are rather poor in comparison with bending strength values presented in other researches (Dawczyński et al., 2016). However, these differences may be caused by many factors such as manufacturing parameters (method and time of mixing, amount of water added to the mixture) or time and temperature of curing (Adam and 
Horianto, 2014). Therefore, further series of strength test are necessary to examine the behaviour of geopolymers subjected to flexure better and to draw more detailed conclusions. Moreover, the investigation concerning material microstructure and particle morphology need to be performed in order to determine the exact causes of strength loss.

While taking into consideration the results of uniaxial compression test, it can be noticed that compressive strength of glassbased geopolymers increases with growing content of ground glass. Analysing the values in Table 4, the compressive strength rises almost linearly with an increase of ground glass content up to $60 \% \mathrm{w} / \mathrm{w}$. The differences in strength between samples GG20, GG40 and GG60 are not greater than $5 \mathrm{MPa}$. With an increase of glass content up to $80 \% \mathrm{w} / \mathrm{w}$ the measured compressive strength reaches about $50 \mathrm{MPa}$, which is almost four times higher than in case of sample that contains $60 \% \mathrm{w} / \mathrm{w}$ ground glass. Such a good compression behaviour may be connected with smaller amount of water introduced into the mixture during preparatory works. According to the literature, an evaporation of water from highly saturated samples may lead to drying shrinkage and surface cracks occurrence. This in turn may cause material weakening and compressive strength reduction (Provis and van Deventer, 2009). Moreover, the results obtained by (Zaharaki and Komnitsas, 2009), partially confirm the behaviour observed in the following test. It was indicated that an addition of glass powder up to $50 \% \mathrm{w} / \mathrm{w}$ does not strongly influence the compressive strength of geopolymers which remains almost the same. They also reported that an increase of glass content above $90 \% \mathrm{w} / \mathrm{w}$ results in rapid compressive strength growth. Therefore, further series of strength test are required in order to examine such behaviour better and to identify the causes of the rapid strength increase.

\section{CONCLUSIONS}

On the basis of the results of three-point bending test and uniaxial compression test the following conclusions can be drawn:

- Flexural strength of glass-based geopolymer samples increases with an increase of ground glass addition up to $60 \%$ $\mathrm{w} / \mathrm{w}$. Addition of glass powder up to $80 \% \mathrm{w} / \mathrm{w}$ leads to bending strength reduction;

- The most favourable composition in terms of flexural strength was obtained for geopolymer sample composed of $60 \%$ $\mathrm{w} / \mathrm{w}$ glass. In this case, the measured strength was equal to $3.1 \mathrm{MPa}$;

- Compressive strength of geopolymer samples composed of $20 \%, 40 \%, 60 \%$ and $80 \%$ w/w glass increases with increasing ground glass content;

- The most favourable composition in terms of compressive strength was obtained for geopolymer specimen composed of $80 \% \mathrm{w} / \mathrm{w}$ glass. In this case, the measured strength was equal to $48.8 \mathrm{MPa}$.

The mechanical properties of the tungsten mine waste geopolymeric binder depends not only on the proportion of the materials used (precursor as well as activator) but also on temperature and time of curing. In this case, to reduce the number of laboratory tests, numerical analysis may be helpful, but it requires a proven material model. An example of such an analysis is presented in the paper (Górski et al., 2016).

\section{ACKNOWLEDGEMENTS}

This paper has been prepared with the financial support of European Union's Horizon 2020 Research and Innovation Staff Exchange (RISE) programme (Marie Skłodowska-Curie Actions) under grant agreement no. 645696, project REMINE (Reuse of Mining Waste into Innovative Geopolymeric-based Structural Panels, Precast, Ready Mixes and Insitu Applications) and Polish Ministry of Science and Higher Education project no. 341284/PnH/2016.

\section{REFERENCES}

Adam, A. A., Horianto (2014). The effect of temperature and duration of curing on the strength of fly ash based geopolymer mortar. Procedia Engineering, 95, 410-414.

Christiansen, M.U. (2013). An Investigation of Waste Glass-Based Geopolymers Supplemented with Alumina. PhD Thesis, Michigan Technological University.

Davidovits, J. (2008): Geopolymer Chemistry \& Applications. Saint-Quentin: Institut Géopolymere.

Dawczyński, S., Górski, M., Krzywoń, R. (2016). Geopolymer as an alternative ecological material for buildings. Proceedings of 14th International Conference on New Trends in Statics and Dynamics of Buildings. Bratislava: Slovak University of Technology.

Górski, M., Krzywoń, R., Safuta, M., Paszek, N., Dawczyński, S., Pizoń, J. (2016). Laboratory test of material properties of geopolymers made out of postmining waste and their numerical modelling'. Materiały Budowlane, 8, 89-91.

Pacheco-Torgal, F., Castro-Gomes, J. P., Jalali, S. (2005). Geopolimeric Binder Using Tungsten Mine Waste: Primarily Investigation. Geopolymer, Green Chemistry and Sustainable Development Solutions, Geopolymer Institute. 
Pacheco-Torgal, F., Castro-Gomes, J. P., Jalali, S. (2007). Using Mine Waste Mud to Produce Environmentally Friendly New Binders. In Portugal SB07, Sustainable Construction, Materials and Practices, Challenge of the industry for the New Millennium (pp. 912-917). Amsterdam: IOS Press BV.

Pacheco-Torgal, F., Castro-Gomes, J. P., Jalali, S. (2008). Investigations of tungsten mine waste geopolimeric binder: Strength and microstructure. Construction and Building Materials, Vol. 22 (11), 2212-2210.

Provis, J. L., van Deventer, J. S. J. (2009): Geopolymers - Structure, processing, properties and industrial applications. Oxford, Cambridge, New Delhi: Woodhead Publishing Limited.

REMINE (2018). Retrieved from https://reminemsca.wordpress.com

Sangiorgi, C., Lantieri, C., Tatarani, P., Castro-Gomes, J., Gabriel, M. (2016). Reuse of mining waste into innovative alkaliactivated-based materials for road pavement applications. Functional Pavement Design. Erkens et al. (Eds). London: Taylor \& Francis Group.

Vafaei, M., Allahverdi, A. (2017). High strength geopolymer binder based on waste-glass powder. Advanced Powder Technology, Vol. 28 (1), 215-222.

Vickers, L., van Riessen, A., Rickard, W.D.A. (2015): Fire-resistant Geopolymers. Role of Fibres and Fillers to enhance Thermal Properties. Singapore: Springer.

Zaharaki, D., Komnitsas, K. (2009). Effect of additives on the compressive strength of slag-based inorganic polymers. Global NEST Journal, Vol. 11(2), 137-146. 